Egypt. Acad. J. biolog. Sci., 3 (1): 95- 103 (2010)

Email: egyptianacademic@yahoo.com

Received: 30/4 /2010
A. Entomology

ISSN: $1687-8809$

www.eajbs.eg.net

\title{
Changes in protein content of Culex pipiens mosquito treated with two agriculture waste extracts
}

\author{
Reda F. A. Bakr' ${ }^{1}$ Nadia Helmy ${ }^{1}$; Galal A. Nawwar ${ }^{2}$; Somia El. Ibrahim² and \\ Omnia M. Helmy ${ }^{2}$ \\ 1- Department of Entomology, Faculty of Science, Ain-Shams University \\ 2- Applied organic chemistry Department, National Research Centre, Cairo, Egypt
}

\section{ABSTRACT}

Third larval instars of Culex pipiens were exposed to sub-lethal concentration $\mathrm{LC}_{25}$ of Black and White liquors (waste extract from rice straw) for 24 hours to study its effect on protein content quantitative and qualitative. The total protein contents in larval treated either with black liquor or with white liquor were high in all developmental stages except in pupal stage Black liquor treatment was low but not significantly as compared to the control insect. The protein profile of the treated larvae and other developmental stages (pupa, adult female and adult male) was evaluated to explain their mode of action. Electrophoretic analysis of total proteins revealed inhibitory action of the tested compounds on the protein contents. The appearance and disappearance of certain protein fractions by application of these compounds may be explain their larvicidal activity and disorders occurred during different developmental stages.

Keywords: Protein, Culex pipiens, Agriculture waste extracts

\section{INTRODUCTION}

Mosquitoes are still the world's number one vectors of human and animal diseases; and are conspicuous nuisance pests as well, even after massive efforts of eradication or control. The extensive use of chemical pesticides or insecticides resulted in inducing resistance by insect pests besides, residue contamination of human food, mammalian toxicity and environmental pollution. These factors have created the need for environmental safe, degradable and target specific agents for pest control purposes. Plant extracts have gained importance in insect control, being considered environmentally safe, less hazardous to non target biota, simple inexpensive and can be applied effectively by using techniques more suitable for developing countries (Soliman \& El-Serif, 1995; El-Bokl \& Moawed, 1996; Shoukry \& Hussein, 1998, Massoud \& Labib, 2000; Mohammed \& Hafez, 2000 and Mohammed, et al., 2003).

Several plant extracts were effective as potential acute or chronic insecticides, insect growth inhibitors or antifeedants against a variety of insect species (Jilani \& Saxena, 1990; Shapiro, et al., 1994; Abd el-Baky, et al., 2005; Bakr, et al., 2006 and Bakr, et al., 2008). Such larval intoxication and growth regulator of immature and adult mosquitoes were found correlated with some biochemical changes in the tested species particularly in a decrease or increase of the total and certain protein fraction patterns which may lead to certain functional and physiological interactions (El-Bokl, et al., 1998; Mohammed \& Hafez, 2000, Massoud, et al., 2001 and Mohammed, et al., 2003). The present work was conducted to study the effect of sub-lethal dosage of 
waste extract (rice straw extract) on protein content quantitative and qualitative of Culex pipiens.

\section{MATERIALS AND METHODS}

\section{Tested mosquitoes: \\ Culex pipiens (Culicidae: Diptera)}

Larvae of Culex pipiens provided from Medical Entomology Institute and transferred to the laboratory of Entomology Department - Faculty of Science - Ain Shams University where self-perpetuating colonies were established and maintained during the present study.

\section{Tested compounds:}

Black liquor produced from the paper production industry but in new way patent No.، (422 / 2008).

White liquor was effluent from bleaching paper that introduced in paper production industry (Sreekrishnan, 2001) with modification, using sod. hyposulphite at $60^{\circ} \mathrm{C}$ with stirring for one day.

\section{Biochemical studies:}

Each of selected compounds was applied on larvae at concentration of LC25 level for $24 \mathrm{hrs}$. Then survived larvae post treatment were gently washed with tape water and transferred to labeled pans. Some of these survived larvae and other developmental stages emerged from treated larvae was collected and submitted to biochemical studies.

\section{Preparation of insects for analysis:}

\section{A. For quantitative total protein:}

Insects were homogenized for biochemical analysis in a chilled glass Teflon tissue homogenizer (ST-2 Mechanic-Preczyina, Poland) with ice-cold saline buffer $(0.9 \% \mathrm{NaCL})$. After homogenation, centrifuged at 4000 r.p.m. for $20 \mathrm{~min}$. at $4^{\circ} \mathrm{C}$, supernatants were kept in a deep freezer at $-20^{\circ} \mathrm{C}$ till use for biochemical assays.

\section{B. For fractionation of protein:}

Insects were homogenized with liquid nitrogen and buffer solution; $(0.125 \mathrm{M}$ Tris, 2\% SDS, 10\% glycerol, 5\% 2-mercaptothanol, $0.001 \%$ bromophenol blue) centrifuged at 4000 r.p.m. for $20 \mathrm{~min}$. at $4{ }^{\circ} \mathrm{C}$. The supernatants of centrifuged insect's tissues were with drown carefully using automatic pipettes and transferred to a new Eppendorf tube and kept frozen at $-70^{\circ} \mathrm{C}$ till used.

\section{Total protein measurement:}

Total proteins were determined by the method of Bradford (1976). Protein reagent was prepared by dissolving $100 \mathrm{mg}$ of Coomassie Brilliant blue G-250 in $50 \mathrm{ml}$ $95 \%$ ethanol. To this solution $100 \mathrm{ml} 85 \%(\mathrm{~W} / \mathrm{V})$ phosphoric acid were added. The resulting solution was diluted to a final volume of 1 liter. Sample solution $(50 \mu 1)$ or for preparation of standard curve $50 \mu$ l of serial concentrations containing 10 to $100 \mu \mathrm{g}$ bovine serum albumin were pipetted into test tubes. The volume in the test tube was adjusted to $1 \mathrm{ml}$ with phosphate buffer $(0.1 \mathrm{M}, \mathrm{pH} 6.6)$. Five millimeters of protein reagent were added to test tube and the contents were mixed. The absorbance at 595 $\mathrm{nm}$ was measured after $2 \mathrm{~min}$ and before $1 \mathrm{hr}$ against blank prepared from $1 \mathrm{ml}$ of phosphate buffer and $5 \mathrm{ml}$ protein reagent. Data analyzed by SPSS ver. 16 .

\section{Electrophoretic analysis:}

Protein fractionated by SDS polyacrylamide gel electrophoresis (PAGE) as described by Smith (1976); using slab gel that consist of a $4 \%$ polyacrylamide stacking gel and an acrylamide (12\%) gel. High and low MW standards were used for the determination of protein profiles of all fractionated samples. Electrophoresis was 
done at $27 \pm 2{ }^{\circ} \mathrm{C}$ using $20 \mathrm{~m} \mathrm{~A} /$ plate for approximately $6 \mathrm{~h}$. The gels were then stained with Coomassie blue for protein. The gels were photographed and scanned using a gel-pro analyzer (Gel Document advantage Ver. 3.0) was used for the protein analysis of tested samples. This program is a comprehensive computer software application designed to determine the number, molecular weight and the amounts of peptide chains as well as scanned graphical presentation of the fractionated bands of each lane.

\section{RESULTS}

\section{Total protein content:}

Results represented in Table (1) indicated that, the amount of total protein in adult male more than other stages in black and white liquors larval treatments, in which they were 20.83 and $19.05 \mathrm{mg} / \mathrm{g}$. b.wt, respectively. Black liquor larval treatment, pupal stage showed the lowest amount of total protein as compared with the other stages, which were $15.53 \mathrm{mg} / \mathrm{g}$. b.wt. While white liquor larval treatment, adult female stage showed the lowest amount of total protein as compared with the other stages, which were $17.19 \mathrm{mg} /$ g.b.wt.

Table 1: Total protein contents in different developmental stages of Culex pipiens larval treatment with black and white liquors in comparison with non treated stages:

\begin{tabular}{|c|c|c|c|c|c|c|c|c|}
\hline \multirow[b]{2}{*}{$\begin{array}{c}\text { Tested } \\
\text { compounds }\end{array}$} & \multicolumn{4}{|c|}{ Total protein in $\mathrm{mg}$ / g.b.wt. } & \multicolumn{4}{|c|}{ Total protein ratio* } \\
\hline & Larvae & Pupae & $\begin{array}{l}\text { Adult } \\
\text { female }\end{array}$ & $\begin{array}{l}\text { Adult } \\
\text { male }\end{array}$ & Larvae & Pupae & $\begin{array}{l}\text { Adult } \\
\text { female }\end{array}$ & Adult male \\
\hline Black liquor & 15.12 & 15.53 & 19.65 & 20.83 & 1.01 & 0.84 & 1.08 & 1.2 \\
\hline White liquor & 16.29 & 19.05 & 17.19 & 19.05 & 1.09 & 1.03 & 0.94 & 1.1 \\
\hline Control & 14.96 & 18.42 & 18.26 & 17.23 & - & - & - & - \\
\hline \multicolumn{9}{|c|}{ Total protein in treated stages } \\
\hline
\end{tabular}

It is clear that the total protein contents in larval treated either with black liquor or with white liquor were higher than control in all developmental stages except in pupal stage Black liquor treatment was lower than control at $\mathrm{P} \geq 0.05$.

The values of the total protein ratio in the larvae, pupae, adult female and adult male which treated with black liquor were $1.01,0.84,1.08$ and 1.2, respectively.

Whereas, the values of the total protein ratio in the larvae, pupae, adult female and adult male which treated with white liquor were 1.09, 1.03, 0.94 and 1.1, respectively.

\section{Protein fraction:}

Changes in total protein profile of the treated Culex pipiens larvae with Black and White liquors as comparing with control group are presented in the Fig (1) \& Table $(2 \& 3)$ one band only No. 10 (Mwt 68.5 KDa) was common between control and White liquor treatment. Five bands, No. 3, 7, 11, 14 and 17 (Mwt 163.7, 88, 65.1, $57 \% 48.8 \mathrm{KDa}$, respectively) were disappeared in the treated larvae with tested compounds, while they were detected in control group. Bands No. 8 and 18 (Mwt $83.3 \% 40 \mathrm{KDa}$, respectively) were detected in treated larvae with both treatments, while they disappeared in control group. Bands No. 2, 5, 12 and 16 (Mwt $>$ 203, 122.4 , $63.4 \& 52.6 \mathrm{KDa}$, respectively) were appeared only in larvae treated with White liquor. Bands No. 1, 4, 6, 9, 13, 15 \& 19 (Mwt > 203, 143.8, 94.4, 70, 59.1, 55 \& $38.4 \mathrm{KDa}$, respectively) were appeared only in larvae which treated with Black liquor. 
Table (2): Relative mobility and concentration of different SDS protein bands detected in the whole homogenates treated Culex pipiens larvae with White and Black liquors in comparison with control.

\begin{tabular}{|c|c|c|c|c|c|}
\hline Band No. & Rm & Molecular weight KDa & Control & White & Black \\
\hline 1 & 0.03 & $>203$ & - & - & 11.44 \\
\hline 2 & 0.04 & $>203$ & - & 17.18 & - \\
\hline 3 & 0.05 & $>203$ & 22.51 & - & - \\
\hline 4 & 0.1 & 129.8 & - & - & 10.44 \\
\hline 5 & 0.14 & 97.2 & - & 12.79 & - \\
\hline 6 & 0.24 & 62.8 & - & - & 13.32 \\
\hline 7 & 0.26 & 60.8 & 10.13 & - & - \\
\hline 8 & 0.27 & 59.1 & - & 19.74 & 5.32 \\
\hline 9 & 0.33 & 51.1 & - & - & 11.28 \\
\hline 10 & 0.34 & 48.8 & 15.32 & 12.02 & - \\
\hline 11 & 0.48 & 30 & 16.47 & - & - \\
\hline 12 & 0.49 & 27.3 & - & 11.05 & - \\
\hline 13 & 0.5 & 27 & - & - & 12.53 \\
\hline 14 & 0.55 & 25.3 & 23 & - & - \\
\hline 15 & 0.57 & 24 & - & - & 19.08 \\
\hline 16 & 0.58 & 23.6 & - & 16.52 & - \\
\hline 17 & 0.59 & 23 & 12.57 & - & - \\
\hline 18 & 0.61 & 25 & - & 10.7 & 8.47 \\
\hline 19 & 0.74 & 13.8 & - & - & 8.13 \\
\hline
\end{tabular}

Table 3: Relative mobility and concentration of different SDS protein bands detected in the whole homogenates pupae emerged from treated Culex pipiens larvae with White and Black liquors in comparison with control.

\begin{tabular}{|c|c|c|c|c|c|}
\hline Band No. & $\mathrm{Rm}$ & Molecular weight KDa & Control & White & Black \\
\hline 1 & 0.02 & $>203$ & - & 9.45 & - \\
\hline 2 & 0.03 & $>203$ & 7.69 & - & 10.39 \\
\hline 3 & 0.08 & 163.7 & - & - & 9.64 \\
\hline 4 & 0.09 & 143.8 & 6.72 & - & - \\
\hline 5 & 0.11 & 122.4 & - & - & 6.79 \\
\hline 6 & 0.14 & 94.4 & - & 12.94 & 6.97 \\
\hline 7 & 0.16 & 88 & 10.03 & - & - \\
\hline 8 & 0.17 & 83.3 & - & 5.28 & - \\
\hline 9 & 0.19 & 70 & 3.97 & - & - \\
\hline 10 & 0.21 & 68.5 & - & - & 16.07 \\
\hline 11 & 0.23 & 65.1 & - & 11.77 & - \\
\hline 12 & 0.24 & 63.4 & 12.01 & - & - \\
\hline 13 & 0.27 & 59.1 & - & - & 7.04 \\
\hline 14 & 0.29 & 57 & - & - & 6.79 \\
\hline 15 & 0.3 & 55 & - & 7.85 & - \\
\hline 16 & 0.32 & 52.6 & 5.25 & - & - \\
\hline 17 & 0.34 & 48.8 & 3.91 & - & - \\
\hline 18 & 0.37 & 40 & - & 8.37 & - \\
\hline 19 & 0.39 & 38.4 & 8.38 & - & 9.61 \\
\hline 20 & 0.43 & 34.7 & 5.62 & - & - \\
\hline 21 & 0.46 & 32.2 & - & 9.5 & - \\
\hline 22 & 0.51 & 26.7 & - & - & 10.41 \\
\hline 23 & 0.54 & 25.5 & - & 6.69 & 7.6 \\
\hline 24 & 0.55 & 25.2 & 6.26 & - & - \\
\hline 25 & 0.62 & 21.4 & 7.83 & 10.73 & - \\
\hline 26 & 0.67 & 19.4 & 5.43 & - & - \\
\hline 27 & 0.78 & 16.4 & 7.32 & 8.72 & - \\
\hline 28 & 0.88 & 11.3 & 9.57 & 8.71 & - \\
\hline 29 & 0.94 & 5.5 & - & - & 8.7 \\
\hline \multicolumn{3}{|c|}{ Total number of bands } & 14 & 11 & 11 \\
\hline
\end{tabular}

Densitometry scanning of electropherogram of SDS revealed that, band No. 14 (Mwt $25.3 \mathrm{KDa}$ ) had the highest concentration (23\%) in control group, while band No. 8 (Mwt 59.1KDa) had the highest concentration $(19.74 \%$ ) in larvae treated with White liquor. In case of Black liquor treatment band No. 15 (Mwt $24 \mathrm{KDa}$ ) had the highest concentration (19.08\%) as shown in Table (2). Emerged pupae from both larval treatments (White and Black liquors) and control of Culex pipiens where size fractionated into 29 bands There were three common bands between control group and White liquor treatment, bands No. 25, 27 and 28 (Mwt 21.4, 16.4 \& 11.3 KDa, respectively) and two common bands between control group and Black liquor treatment, bands No.2 \& 19 (Mwt $>203 \& 38.4 \mathrm{KDa}$, respectively). Also, there were two common bands between both treatments, bands No. 6 \& 23 (Mwt $94.4 \& 25.5$ 
KDa, respectively) Bands No. 4, 7, 9, 12, 16, 17, 20, 24 \& 26 (Mwt 143.8, 88, 70, $63.4,52.6,48.8,34.7,25.2 \& 19.4 \mathrm{KDa}$, respectively) appeared only in control group. Bands No. 1, 8, 11, 15, 18 \& 21 (Mwt > 203, 83.3, 65.1, 55, 40 \& 32.2 KDa, respectively) were detected only in White liquor treatment. Bands No. 3, 5, 10, 13, 14, 22 \& 29 (Mwt 163.7, 122.4, 68.5, 59.1, 57, $26.7 \& 5.5 \mathrm{KDa}$, respectively) were appeared only in Black liquor treatment as shown on Table (3) \& Fig. (1).

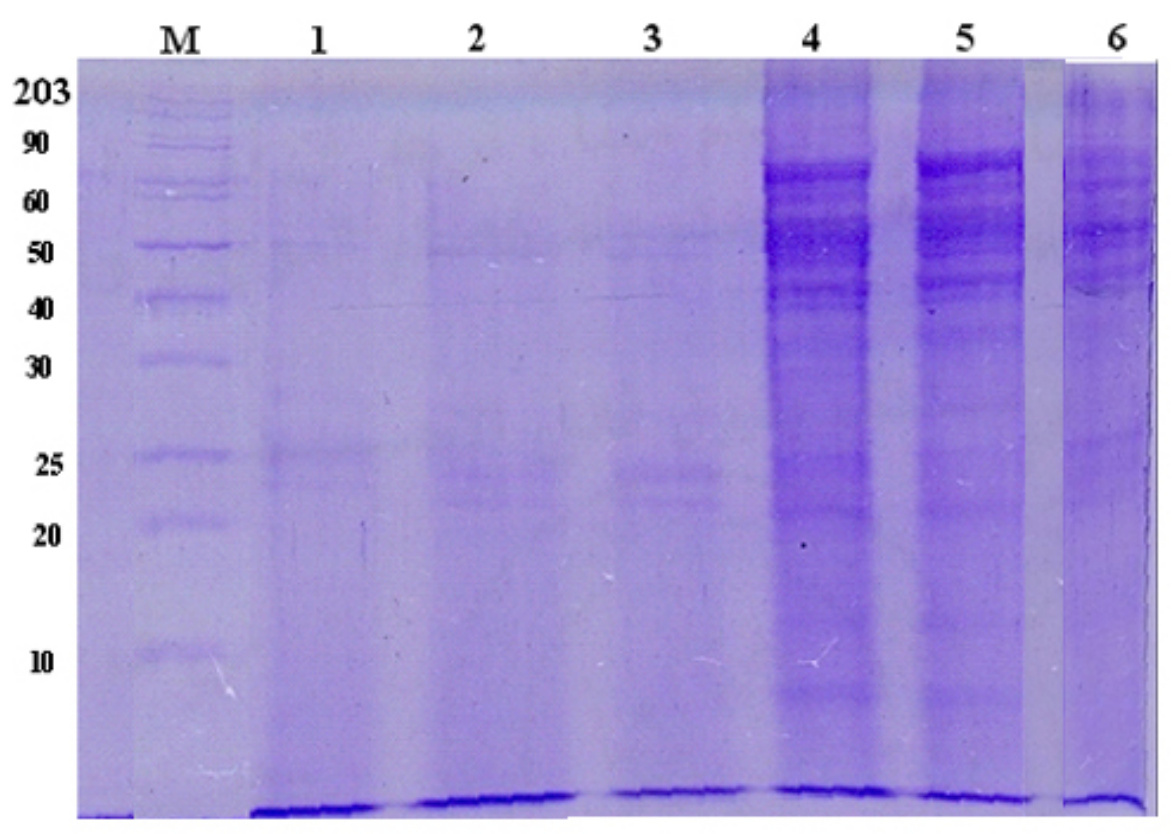

Fig. 1: Photograph of electrophoretic protein pattern of larvae and pupae stages of Culex pipiens as control and treated sample with two extract Black and White liquors.
Where: M Marker
$1=$ Control larvae
$2=$ Larvae treated by White liquor
$3=$ Larvae treated by Black liquor
$4=$ Pupae emerged from control larvae
$5=$ Pupae emerged from larvae treated by White liquor
$6=$ Pupae emerged from larvae treated by Black liquor

Densitometric scanning of electrophergram of SDS protein (Table 3) revealed that, band no. 12 (Mwt $63.4 \mathrm{KDa}$ ) had the highest concentration $(12.01 \%)$ in control group. Band No. 6 (Mwt 94.4) had the highest concentration (12.94\%) in White liquor treatment, while band No.10 (Mwt 68.5 KDa) had the highest concentration (16.07\%) in Black liquor treatment. Adult female which emerged from larval treatment with both tested compounds (White and Black liquors) and control group of Culex pipiens were size fractionated into 21 bandsas shown in Table (4) \& Fig. (2). One common band appeared in control and both treatments No. 10 (Mwt 44.6 KDa). Also, there were three bands No. 14, 16, 21 (Mwt 34.7, 17 \& $10.7 \mathrm{KDa}$, respectively) appeared commonly between control group and White liquor treatment. Bands No. 1, 4, 8, 11 \& 15 (Mwt 117.9, 63.4, 55, 39.2 \& $30.9 \mathrm{KDa}$, respectively) were detected in control group only. Bands No. 2, 5, 6, 9, 12 \& 19 (Mwt 65.7, 62.6, 60, 54.1, 38.4 \& 13.3 $\mathrm{KDa}$, respectively) appeared only in White liquor treatment, while bands No. 3, 7, 13, 17, 18 \& 20 (Mwt 65.1, 57, 36.6, 15, 13.5 \& $11 \mathrm{KDa}$, respectively) appeared only in Black liquor treatment. Densitometric scanning of electropherogram of SDS protein 
showed that, band No. 10 (Mwt 44.6 KDa) had the highest concentration (13.17\%) in control group (Table 4).

Table 4: Relative mobility and concentration of different SDS protein bands detected in the whole homogenates adult female emerged from treated Culex pipiens larvae with White and Black liquors in comparison with control.

\begin{tabular}{|c|c|c|c|c|c|}
\hline Band No. & $\mathrm{Rm}$ & Molecular weight KDa & Control & White & Black \\
\hline 1 & 0.07 & 117.9 & 12.04 & - & - \\
\hline 2 & 0.22 & 65.7 & - & 10.66 & - \\
\hline 3 & 0.23 & 65.1 & - & - & 12.54 \\
\hline 4 & 0.24 & 63.4 & 11.41 & - & - \\
\hline 5 & 0.25 & 62.6 & - & 9.17 & - \\
\hline 6 & 0.28 & 60 & - & 9.29 & - \\
\hline 7 & 0.29 & 57 & - & - & 12.8 \\
\hline 8 & 0.3 & 55 & 12.39 & - & - \\
\hline 9 & 0.31 & 54.1 & - & 9.64 & - \\
\hline 10 & 0.35 & 44.6 & 13.17 & 9.61 & 19.21 \\
\hline 11 & 0.38 & 39.2 & 8.1 & - & - \\
\hline 12 & 0.39 & 38.4 & - & 9.37 & - \\
\hline 13 & 0.41 & 36.6 & - & - & 12.51 \\
\hline 14 & 0.43 & 34.7 & 10.79 & 10.09 & - \\
\hline 15 & 0.47 & 30.9 & 9.16 & - & - \\
\hline 16 & 0.69 & 17 & 11.78 & 9.24 & - \\
\hline 17 & 0.7 & 15 & - & - & 19.51 \\
\hline 18 & 0.75 & 13.5 & - & - & 11.78 \\
\hline 19 & 0.76 & 13.3 & - & 12.04 & - \\
\hline 20 & 0.85 & 11 & - & - & 11.64 \\
\hline 21 & 0.86 & 10.7 & 11.16 & 10.89 & \\
\hline & Total number of bands & 9 & 10 & 7 \\
\hline
\end{tabular}

Band No.19 (Mwt 13.3 KDa) had the highest concentration (12.04\%) in White liquor treatment, while band No. 17 (Mwt $15 \mathrm{KDa}$ ) had the highest concentration (19.51\%) in Black liquor treatment. Adult male which emerged from larval treatment with both tested compounds (White \& Black liquors) and control group of Culex pipiens were size fractionated into 26 bands as shown in table (5) \& Fig (2).

Table 5: Relative mobility and concentration of different SDS protein bands detected in the whole homogenates adult male emerged from treated Culex pipiens larvae with White and Black liquors in comparison with control.

\begin{tabular}{|c|c|c|c|c|c|}
\hline Band No. & Rm & Molecular weight KDa & Control & White & Black \\
\hline 1 & 0.08 & 111.9 & - & - & 6.26 \\
\hline 2 & 0.09 & 100 & - & - & 6.41 \\
\hline 3 & 0.12 & 91.2 & - & - & 6.05 \\
\hline 4 & 0.15 & 82.3 & - & - & 6.48 \\
\hline 5 & 0.2 & 68.3 & - & - & 6.46 \\
\hline 6 & 0.23 & 65.1 & 8.41 & 8.99 & 6.24 \\
\hline 7 & 0.28 & 60 & - & - & 7.55 \\
\hline 8 & 0.29 & 57 & 8.5 & 9.06 & - \\
\hline 9 & 0.31 & 54.1 & - & - & 7.14 \\
\hline 10 & 0.33 & 51.1 & 8.32 & - & - \\
\hline 11 & 0.34 & 48.8 & - & 8.9 & - \\
\hline 12 & 0.36 & 44 & 11.01 & - & 7.54 \\
\hline 13 & 0.38 & 39.2 & - & 10.15 & 7.13 \\
\hline 14 & 0.42 & 35.9 & 7.96 & 8.56 & - \\
\hline 15 & 0.43 & 34.7 & - & - & 6.92 \\
\hline 16 & 0.45 & 33.1 & 7.88 & - & - \\
\hline 17 & 0.46 & 32.2 & - & 8.5 & 6.65 \\
\hline 18 & 0.48 & 30 & 7.6 & - & - \\
\hline 19 & 0.61 & 25 & - & - & 6.23 \\
\hline 20 & 0.69 & 17 & 10.53 & 12.87 & - \\
\hline 21 & 0.7 & 15 & - & - & 6.81 \\
\hline 22 & 0.74 & 13.8 & - & 12.26 & - \\
\hline 23 & 0.77 & 13.1 & 11.29 & - & - \\
\hline 24 & 0.84 & 11.2 & 7.25 & 10.56 & 6.14 \\
\hline 25 & 0.89 & 10 & 11.25 & - & - \\
\hline 26 & 0.91 & 7.8 & - & 10.14 & - \\
\hline & Total number of bands & 11 & 10 & 15 \\
\hline & & & & & \\
\hline & & & & & \\
\hline
\end{tabular}




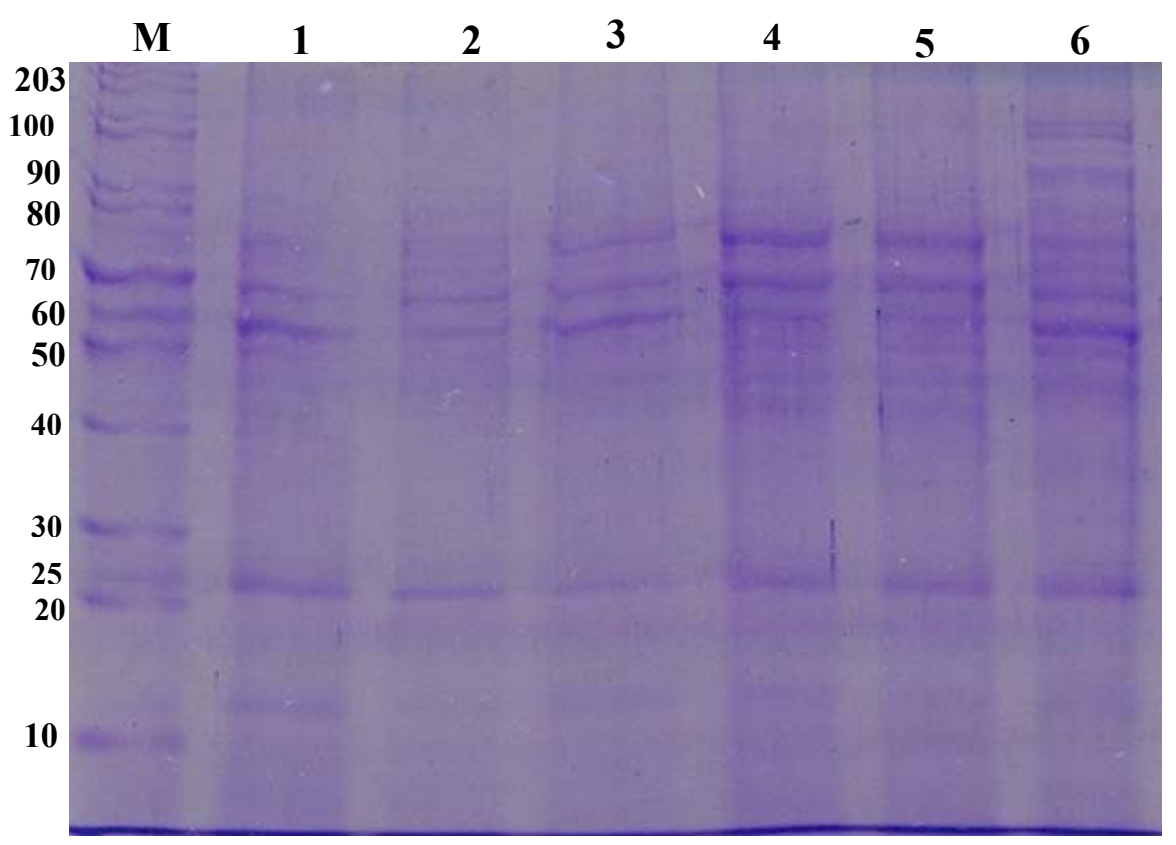

Fig. 2: Photograph of electrophoretic protein pattern of adult female and adult male stages of Culex pipiens as control and treated sample with two extract Black and White liquors.

Where: M Marker

$1=$ Adult female emerged from control larvae

$2=$ Adult female emerged from larvae treated by White liquor

$3=$ Adult female emerged from larvae treated by Black liquor

$4=$ Adult male emerged from control larvae

$5=$ Adult male emerged from larvae treated by White liquor

$6=$ Adult male emerged from larvae treated by Black liquor

Two bands were common between control and both treatments, the bands No. 6 \& 24 (Mwt 65.1 \& 11.2 KDa, respectively). Bands No. 8, 14 \& 20 (Mwt 57, 35.9 \& $17 \mathrm{KDa}$, respectively) were detected in control group and White liquor treatment only. Bands No. 10, 16, 18, 23 \& 25 (Mwt 50, 33.1, 30, 13.1 \& $10 \mathrm{KDa}$, respectively) appeared only in control group. Also, bands No. 11, $22 \& 26$ (Mwt 48.8, 13.8 \& 7.8 KDa, respectively) appeared in White liquor treatment only. Bands no. 1, 2, 3, 4, 5, 7 , 9, 15, 19 \& 21 (Mwt 111.9, 100, 91.2, 82.3, 68.3, 60, 54.1, 34.7, 25 \& $15 \mathrm{KDa}$, respectively) appeared in Black liquor treatment only. Densitometric scanning of electropherogram of SDS protein (Table 5) revealed that, band no. 23 (Mwt 13.1 $\mathrm{KDa}$ ) had the highest concentration (11.29\%) in control group. Band No. 20 (Mwt 17 $\mathrm{KDa}$ ) had the highest concentration $(12.87 \%)$ in White liquor treatment, while band No. 7 (Mwt $6 \mathrm{KDa}$ ) had the highest concentration (7.55\%) in Black liquor treatment.

\section{DISCUSSION}

The amount of total protein in different developmental stages of $C x$. pipiens which emerged from treated larvae with black and white liquors increased but not significantly as compared to the control insects except in pupal stage emerged from black liquor treatment showed reduction in total protein. Although adult male showed the highest amount of total protein in both treatments but still not significantly as compared to the control. However, no significant change occurred in treated larvae with two compounds but may be a tendency by the larvae to detoxify the white liquor more than black liquor referring to their total protein ratio in larval stage. Wilkinson (1976) stated that proteins help to synthesis microsomal detoxifying enzymes. 
Mohammed and Hafez, (2000) and Mohammed et al., (2003) achieved to similar conclusion when working on Culex pipiens by different natural extracts. Along developmental stages which rose from black liquor treatment decreased amount of total protein more than white liquor treatment may be due to the greater effect of black liquor on insect than white liquor. In this study, the treatment with White and Black liquors produced some differences in SDS protein patterns in larvae and different developmental stages (pupa, adult female and adult male) which emerged from treated Culex pipiens larvae comparing with control group in each stage. The change in arrangement of protein bands control group and treated larvae and other developmental stages of culex pipiens may be attributed to the toxic action of the tested compounds which change the expression process of protein and may be lead to larval mortality and the appearance of latent effect on other developmental stages (pupal mortality, adult mortality, decreased the fecundity of adult female, decreased the hatchability) as concluded by (Mohammed et al., 2003) who treated Culex pipiens larvae by Lemongrass, Red basil, citronella and peppermint as compared with control group.

It is worthy to note that the protein type has specific biological role, due to this role the DNA secretes enzymes which act as catalysts to produce specific type of protein, this protein is responsible for specific biological process, due to the difference in protein band between treated samples and control, the biological process may be affected. Protein fractions that fluctuated in number and relative concentrations depending on the physiological state studied or might be due the protein breakdown and incorporation into other protein or both.

El-Naggar and Abdel-Fattah (1999) showed that, either Eucalyptus oil or its combination with gamma radiation caused quantitative and qualitative changes in protein of larvae and pupae of S. littoralis. El-Bermawy and Abdel-Fattah (2000), found qualitative changes in protein pattern in larvae and pupae of $T$. confusum after treating fourth instar larvae with plant oil (Vetiver). Electrophoretic analysis of total proteins, lipoproteins and glycoproteins revealed inhibitory action of the used plant extract of the Myrrh, namely; oil and oleo resin on the protein contents of Culex pipiens larvae (Massoud et al., 2001). Also, electrophoretic analysis of total protein showed that, appearance and disappearance of some protein bands in the treated Culex pipiens larvae by Lemongrass, Red basil, citronella and peppermint as compared with control group (Mohammed et al., 2003).

\section{REFERENCE}

Abd El-Baky, S. M. M.; Hafez, J. A.; Hamed, M. S. and Kamel, O. M. (2005). Latent effect of Cleome droserifollia extract, Esbiothrin and Alsystin treatments on some biological activities of Ochlerotatus caspius (Diptera: Culicidae). Egypt. Acad. Soc. Environ. Develop., (A-Entomology) 6 (3): 51-60.

Bakr, R. F. A.; ElBermawy, S. M.; Geneidy, N. A. M.; Emara, S. A. and Hassan, H. W. (2006). Occurrence of the biological effects of some plant extracts on the cotton leaf worm Spodoptera littoralis (Biosd) and their physiological. Egypt. Acad. Soc. Environ. Develop., 7 (1): 109-147.

Bakr, R. F. A.; Hussein, M. A.; Hamouda, L. S.; Hassan, H. A. and Elsokary, Z. F. (2008). Effect of some insecticidal agents on some biological aspects and protein patterns of desert locust Schistocerca gregaria (Forskal). Egypt. Acad. Soc. Environ. Develop., 9 (2): $29-42$. 
El-Bermawy, S. M. and Abdel-Fattah, H. M. (2000). Changes in protein electrophoretic pattern of Tribolium confusum $4^{\text {th }}$ instar larva after treatment with volatile plant oil (Vetiver). J. Egypt-Ger. Soc. Zool., 31 (E), Entomol., 167-182.

El-Bokl, M. M. and Moawad, H. M. (1996). Evaluation of some plant extracts as mosquito larvicides. Ain Ahams Sci. Bull., 34: 351-362.

El-Bokl, M. M.; Hamed, M. S. and Moawad, H. M. (1998). Effects of sublethal dosage of plant extracts and Cypermethrin on certain biochemical aspects of the first of filial generation of Culex pipiens larvae. J. Egypt. Ger. Soc. Zool., 26 (E): Entomology.

El-Naggar, S. E. M. and Abdel-Fattah, H. M. (1999). Effects of gamma radiation and plant oil extract of Eucalyptus globules on the cotton leaf worm, Spodoptera littoralis (Boisd). Bull. Ent. Soc. Egypt, Econ. Ser., 26: 59-69.

Jilani, G. and Saxena, R.C. (1990). Repellant and feeding deterrent effects of turmeric oil, sweet flag oil, neem oil and neem-based insecticides against lesser grain borer (Coleoptera: Bostrychidae). J. Con. Entomol., 83 (2): 629-634.

Massoud, A. M. and Labib I. M. (2000). Larvicidal activity of Commiphora molmol against Culex pipiens and Aedes caspius larvae. J. Egypt. Soc. Parasitol., 30 (1): 101- 115.

Massoud, A. M.; Labib, I. M. and Rady, M. (2001). Biochemical changes of Culex pipiens larvae treated with oil and oleo resin extracts of Myrrh commiphora molmol. J. Egypt. Soc. Parasitol., 31 (2): 517-529.

Mohamed, M. I. and Hafez, S. E. (2000). Biological and biochemical effects of the nonvolatile plant oil (Jojoba) against Culex pipiens (Diptera: Culicidae). J. Egypt. Ger. Soc. Zool., 13 (A): 65-78.

Mohamed, M. I.; El-Mohamady, R. H. and Mohamed, H. A. (2003). Larvicidal activity and biochemical effects of certain plant oil extracts against Culex pipiens larvae (Diptera: Culicidae). J. Egypt. Acad. Soc. Environ. Develop. (A. Ent.) 3 (1): 75-93.

Shapiro, M.; Robertson, I. L. and Webb, R. E. (1994). Effect of nemm seed extract upon the gypsy moth (Lepidoptera: Lymantridae) and its nuclear polyhedrosis virus. J. Econ. Entomol., 87: 356-360.

Shoukry, F. I. I. and Hussein, K. T. (1998). Toxicity and biochemical effects of two plant volatile oils on the larvae of the greater wax moth Galleria mellonella L. (Pyralidae: Lepidoptera). J. Egypt. Ger. Soc. Zool., 27 (E): 99-116.

Soliman, B. A. and El-Sherif, L. S. (1995). Larvicidal effect of some plant oils on mosquito Cx. pipiens L. (Diptera: Culicidae). J. Egypt Ger. Soc. Zool., 16 (E): 161-169.

\section{ARABIC SUMMARY}

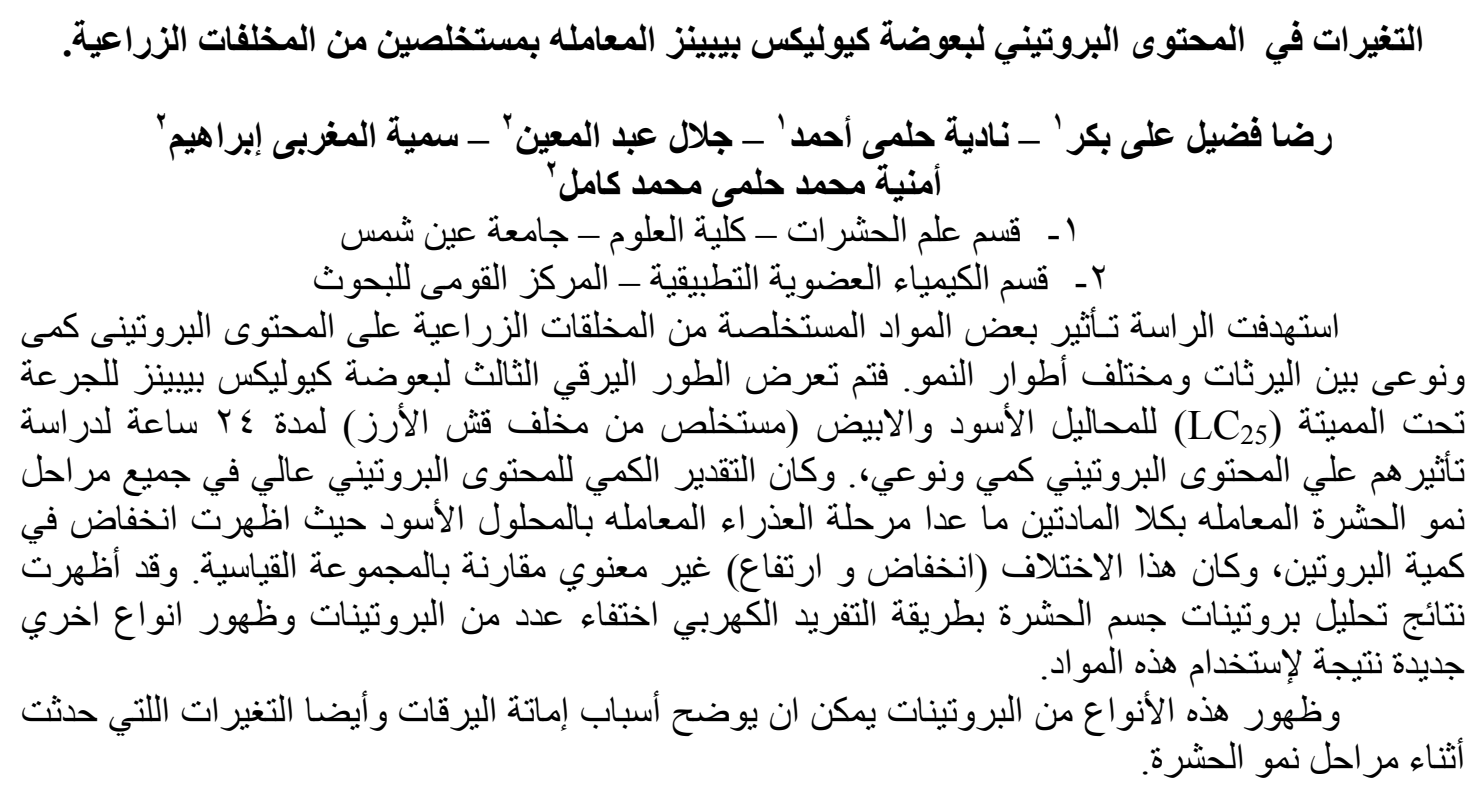

